Pacific Northwest

National Laboratory

Operated by Battelle for the

U.S. Department of Energy

\title{
Aquifer Tube Sampling Along the 100-N Area Shoreline
}

MJ Lindberg

MM Valenta

August 2007

Prepared for the U.S. Department of Energy

under Contract DE-AC05-76RL01830 


\title{
DISCLAIMER
}

This report was prepared as an account of work sponsored by an agency of the United States Government. Neither the United States Government nor any agency thereof, nor Battelle Memorial Institute, nor any of their employees, makes any warranty, express or implied, or assumes any legal liability or responsibility for the accuracy, completeness, or usefulness of any information, apparatus, product, or process disclosed, or represents that its use would not infringe privately owned rights. Reference herein to any specific commercial product, process, or service by trade name, trademark, manufacturer, or otherwise does not necessarily constitute or imply its endorsement, recommendation, or favoring by the United States Government or any agency thereof, or Battelle Memorial Institute. The views and opinions of authors expressed herein do not necessarily state or reflect those of the United States Government or any agency thereof.

\author{
PACIFIC NORTHWEST NATIONAL LABORATORY \\ operated by \\ BATTELLE \\ for the \\ UNITED STATES DEPARTMENT OF ENERGY \\ under Contract DE-AC05-76RL01830
}

Printed in the United States of America
Available to DOE and DOE contractors from the Office of Scientific and Technical Information,
P.O. Box 62, Oak Ridge, TN 37831-0062;
ph: (865) 576-8401
fax: $(865)$ 576-5728
email: reports@adonis.osti.gov

\begin{abstract}
Available to the public from the National Technical Information Service, U.S. Department of Commerce, 5285 Port Royal Rd., Springfield, VA 22161 ph: (800) 553-6847 fax: $(703) 605-6900$ email: orders@ntis.fedworld.gov online ordering: http://www.ntis.gov/ordering.htm
\end{abstract}

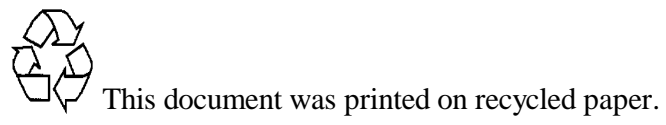




\title{
Aquifer Tube Sampling Along the 100-N Area Shoreline
}

\author{
MJ Lindberg
}

MM Valenta

August 2007

Prepared for the U.S. Department of Energy

under Contract DE-AC05-76RL01830

Pacific Northwest National Laboratory

Richland, Washington 99352 
August 14, 2007

Report number: PNNL-16737

To: Steve Trent

From: Michael Lindberg

Environmental Sciences Laboratory

Subject: Final Results for Sample Delivery Group PNL0052 - SAF Number F07-028

(Aquifer Tube Sampling Along the 100-N Area Shoreline)

This letter contains the following information for sample delivery group PNL0052

- Cover Sheet

- Narrative

- Analytical Results 
Steve Trent

August 14, 2007

Cover Sheet

Page 2

\section{PNNL SAF Number Cross Reference}

Group\#:

Data Deliverable Date:

Data Deliverable:
PNL0052

May 21, 2007

Hard Copy Report

\begin{tabular}{lll} 
SAF Number & Sample ID & Matrix \\
\hline F07-028 & B1MPF8 & Water \\
& B1MPF9 & Water \\
B1MRN4 & Water \\
& B1MPH0 & Water \\
B1MPH1 & Water \\
& B1MPH2 & Water \\
& B1MPH3 & Water
\end{tabular}


Steve Trent

August 14, 2007

Narrative

Page 3

Introduction

On April 4, 2007, 7 water samples were received from the 100-N Area for citrate analysis.

\section{Analytical Results/Methodology}

The analyses for this project were performed at the 325 building located in the 300 Area of the Hanford Site. The analyses were performed according to Pacific Northwest National Laboratory (PNNL) approved procedures. The data sets include the sample identification numbers, analytical results, estimated quantification limits (EQL) and quality control data.

\section{Quality Control}

The preparatory and analytical quality control requirements, calibration requirements, acceptance criteria, and failure actions are defined in the on-line QA plan "Conducting Analytical Work in Support of Regulatory Programs" (CAW). This QA plan implements the Hanford Analytical Services Quality Assurance Requirements Documents (HASQARD) for PNNL.

\section{Definitions}

CCB Continuing Calibration Blank

CCV Continuing Calibration Verification

Spike Matrix Spike

Dup Duplicate

\section{Sample Receipt}

Samples were received with a chain of custody (COC) and were analyzed according to the sample identification numbers supplied by the client. All Samples were refrigerated upon receipt until analyzed.

All samples were received with custody seals intact.

\section{Holding Times}

The prescribed holding times were met for all analytes.

\section{Analytical Results}

All reported analytical results met the requirements of the CAW.

This data package has been reviewed technically for completeness and compliance to the CAW. 
Steve Trent

August 14, 2007

Narrative

Page 4

\section{DISCLAIMER}

This report was prepared as an account of work sponsored by an agency of the United States Government. Neither the United States Government nor any agency thereof, nor Battelle Memorial Institute, nor any of their employees, makes any warranty, express or implied, or assumes any legal liability or responsibility for the accuracy, completeness, or usefulness of any information, apparatus, product, or process disclosed, or represents that its use would not infringe privately owned rights. Reference herein to any specific commercial product, process, or service by trade name, trademark, manufacturer, or otherwise does not necessarily constitute or imply its endorsement, recommendation, or favoring by the United States Government or any agency thereof, or Battelle Memorial Institute. The views and opinions of authors expressed herein do not necessarily state or reflect those of the United States Government or any agency thereof. 
Steve Trent

August 14, 2007

Analytical Results

Page 5

Samples received $4 / 4 / 2007$

Sample Analysis Date:

$5 / 1 / 2007$

Approximate Concentration/Type of Solvent Matrix: Groundwater

Special Analysis Requirements:

Calibration and Standards Prep. Date:

As run

Stock Standards:

BNW LRB 57971

Please contact Mike Lindberg (372-2483) for analysis requests or questions.

Dionex DX600 Chromatographic System RPL Rm 312 Analysis Results: (all results in ppm unless otherwise

stated)

\begin{tabular}{|l|r|}
\hline Sample Name & \multicolumn{1}{|l|}{ Citrate } \\
\hline & ug/mL \\
\hline B1MPF8 & $<1.00 \mathrm{E}-01$ \\
\hline B1MPF9 & $<1.00 \mathrm{E}-01$ \\
\hline B1MPH0 & $1.49 \mathrm{E}-01$ \\
\hline B1MPH1 & $1.76 \mathrm{E}-01$ \\
\hline B1MPH2 & $<1.00 \mathrm{E}-01$ \\
\hline B1MPH3 & $<1.00 \mathrm{E}-01$ \\
\hline B1MRN4 & $<1.00 \mathrm{E}-01$ \\
\hline
\end{tabular}

\begin{tabular}{|l|r|}
\hline Standard Recoveries (\%) & Citrate \\
\hline CCV & 108.29 \\
\hline CCV1 & 103.78 \\
\hline
\end{tabular}

\begin{tabular}{|l|c|}
\hline Spike recoveries $(\%)$ & Citrate \\
\hline B1MPF8 IC SPIKE & 104.83 \\
\hline
\end{tabular}

\begin{tabular}{|l|c|}
\hline Blanks & Citrate \\
\hline CCB & $<1.00 \mathrm{E}-01$ \\
\hline CCB1 & $<1.00 \mathrm{E}-01$ \\
\hline
\end{tabular}

